Further, Chantler et $a l^{8}$ have shown that the copper wire on IUDs becomes rapidly coated with a surface deposit which greatly reduces the release rate of copper and the availability of copper ions.

\section{S BUCKINGHAM}

R A SPARKS

Peter J Watt

Max Elstein

University Department of

Human Reproduction and Obstetrics,

Southampton General Hospital,

Southampton
Southampton Jacobson, L, and Westrom, L, American fournal of
Obstetrics and Gynecology, 1969, 105, 1088. Obstetrics and Gynecology, 1969, 105, 1088.
Gynecology, 1975, 121, 707. 3 Westrom, L, Bengtsson, L P, and Mardh, P, Lancet,
1976, 2, 221.

Buckingham, M S, et al, Paper to be read at the VIII World Congress of Gynaecology and Obstetrics, Mexico City, October, 1976

Elstein, M, Proceedings of the Royal Society of Medicine, 1967, 60, 397 Association, 1975. 231, 711 .

British fournal of Venereal Diseases, 1976, 52, J,

${ }^{8}$ Chantler, E N, Critoph, F, and Elstein, M. In preparation.

\section{Diagnosis of amyloidosis}

SIR,-In a recent short report Mr P Nimoityn and his co-authors (31 July, p 284) report the detection of urinary amyloid in a patient with familial Mediterranean fever. At the conclusion of their comment they state that "the detection of urinary amyloid fibrils by electron microscopy is a practical and non-invasive alternative diagnostic method for patients suspected of having renal amyloidosis." They rightly point out that renal biopsy may be hazardous in patients with renal amyloidosis, but it is surely relevant that in the case they report amyloidosis had already been diagnosed by rectal biopsy.

Since the original report of Gafni and Sohar advocating rectal biopsy as a means of diagnosing generalised amyloidosis there has been ample confirmatory evidence to support biopsy of the rectum as the best and usually the only site required to establish a tissue diagnosis. In contrast to renal or liver biopsy, rectal biopsy is a simple and painless procedure with little or no risk to the patient. In a detailed study of the distribution of amyloid at necropsy in a large number of patients with generalised amyloidosis secondary to the septic complications of paraplegia, rheumatoid arthritis, and tuberculosis $^{23}$ it was shown that the accuracy of rectal biopsy is at least $90 \%$ and that the pattern of distribution of amyloid in the rectum can add useful information to the pattern found throughout the body and the likelihood and rate of renal involvement. In conjunction with Dr Arapakis ${ }^{4}$ rectal biopsy was used as the most appropriate method to estimate the incidence of amyloidosis in rheumatoid arthritis and was found to detect amyloid in a proportion of cases before significant proteinuria was present.

Over the past four years serial rectal biopsy has been used in this hospital both to establish initial diagnosis and to follow the natural history and judge the effect of possible therapeutic agents in a series of 25 patients attending an amyloid clinic. In none of these cases was it thought necessary to perform biopsy of other tissues for either the diagnosis or management of the disease. Apart from slight rectal bleeding in a few cases the patients have suffered no ill effects. Rectal biopsy at sixmonthly intervals provides a permanen histological background to a condition in which the clinical and biochemical findings can vary greatly.

While I admit that the detection of urinary amyloid fibrils is a non-invasive technique, it seems that it is possible only in the late stages of renal amyloidosis and it involves the expensive and not universally available technique of electron microscopy. Since there is ample evidence of both the efficacy and safety of rectal biopsy I would like to suggest that this tried, simple, cheap, reliable, and harmless method remains the histological "sheet anchor" for the diagnosis and management of this stil fatal and little understood condition.

\section{R TRIBE}

Department of Pathology, Bristo

1 Gafni, J, and Sohar, E, American fournal of Medical Sciences, 1960, 240, 332

Tribe, C R, in Modern Trends in Rheumatology, $\mathrm{p} 121$. London, Butterworths, 1966.

Tribe, C R, and Silver, J R, Renal Failure in Paraplegia, pp 54-90. London, Pitman Medical, 1969. Arapakis, G, and Tribe, C R, Annals of the Rheumatic Diseases, 1963, 22, 256 .

\section{Diabetic ketoalkalosis}

SIR,-We read with great interest the recent reports of diabetic ketoalkalosis by Drs $\mathrm{K} \mathrm{C}$ Lim and $\mathrm{C} \mathrm{H}$ Walsh (3 July, p 19) and Dr Elaine B Melrose and others (24 July, p 237) in which it was suggested that diabetic ketoalkalosis was due to severe vomiting or alkali ingestion. We wish to report a case of diabetic ketoalkalosis in which there was no history of alkali ingestion, no vomiting, and no hypokalaemia.

The 70-year-old patient, a long-standing diabetic capable of giving a good history, was admitted for stabilisation of her diabetes before amputation of her right leg for gangrene of the foot. The results of the biochemical investigations on admission were: blood glucose $26.4 \mathrm{mmol} / 1(476 \mathrm{mg} / 100 \mathrm{ml})$ $\mathrm{pH} 7 \cdot 47, \mathrm{PcO}_{2} 5.6 \mathrm{kPa}(42 \mathrm{~mm} \mathrm{Hg})$, standard bicarbonate $29.5 \mathrm{mmol}(\mathrm{mEq}) / 1$, base excess + 6 $\mathrm{mmol}(\mathrm{mEq}) / 1$. There were ketones ++ in the urine. Fourteen hours later, during which time she had received a total of 56 units of soluble insulin but no intravenous fluids, the blood glucose had fallen to $9.8 \mathrm{mmol} / 1(177 \mathrm{mg} / 100 \mathrm{ml})$, but she remained alkalotic, the blood $\mathrm{pH}$ being $7.51, \mathrm{Pco}_{2}$ $5.2 \mathrm{kPa}(39 \mathrm{~mm} \mathrm{Hg})$, standard bicarbonate 31.5 $\mathrm{mmol}(\mathrm{mEq}) / 1$, and base excess $+7.5 \mathrm{mmol}$ $(\mathrm{mEq}) / 1$. At this time, serum urea and electrolyte levels were normal, notably the potassium level, which was $3.6 \mathrm{mmol}(\mathrm{mEg}) / 1$.

The occurrence of ketoalkalosis in a diabetic in whom there was no clinical evidence for the condition emphasises the need already stressed by the previous authors for biochemical monitoring of the acid-base state before applying corrective measures.

R SHIRLEY

J V MARTIN

Department of Chemical Pathology

Royal Hospit

\section{Ketamine hydrochloride:}

a potent analgesic

SIR,- The following case report demonstrates the powerful analgesic effect of subdissociative doses of ketamine hydrochloride.

A 59-year-old steel erector fell from scaffolding racturing several ribs, which resulted in a flail chest. While clinically he could just about manage with this embarrassment to respiration, it became necessary for him to undergo laparotomy for carcinoma of the colon, which had been found while he was in hospital. The following day the patient, now with a transverse colostomy and a flail chest, was in respiratory failure, mainly owing to retention of bronchial secretions due to the severe pain of adequate coughing. His $\mathrm{PCO}_{2}$ was $5.6 \mathrm{kPa}(42 \mathrm{~mm}$ $\mathrm{Hg}), \mathrm{Po}_{2} 8 \mathrm{kPa}(60 \mathrm{~mm} \mathrm{Hg})$, and base excess $9 \mathrm{mmol}(\mathrm{mEq}) / 1$

It was felt that if effective coughing could be re-established it might be possible to manage the case without ventilation, which at the time would have been difficult to institute because of extreme pressure on intensive care beds. Further deterioration in the blood gases, which were frequently measured, would, of course, have been treated with intermittent pressure ventilation.

Ketamine hydrochloride, given in subdissociative dosage, is the only analgesic powerful enough to allay this degree of pain without causing respiratory depression. Accordingly ketamine $0.5 \mathrm{mg}$ per $\mathrm{kg}$ was given intravenously. In less than two minutes the patient volunteered that he was pain-free for the first time since his fall. On request he gave a respectable cough, bringing up sputum. Simultaneous physiotherapy resulted in the clearing of secretions. This process was repeated three times daily for the next three days. The patient made good progress and never needed ventilation as he almost certainly would have done otherwise.

The psychotomimetic reaction or unpleasant dreams experienced when the full, dissociative dosage of ketamine is used (around $2 \mathrm{mg} / \mathrm{kg}$ intravenously) is not a problem at this dosage level.1-5 Consequently fear of causing these reactions need not deter the clinician from using this valuable, safe, and powerful analgesic where appropriate.

T R Austin

Cardiff Royal Infirmary,

${ }^{1}$ Hyman, M D, Anesthesiology Review, 1974, 1, 17

Chodoff, P, and Stella, J G, Anesthesia and Analgesia -Current Research, 1966, 45, 52

Corssen, G, et al, Fournal of Oral Surgery, 1969, 27

627. Researches, 1974, 53, 354

Liang, H S, and Liang, H G, Anesthesia and Analgesia Current Researches, 1975, 54, 312.

Security units for dangerous and difficult patients

SIR,-May I congratulate Dr J H Price on his thoughtful letter on security units (25 September, p 756)? As a forensic psychiatrist actively involved in the new developments I too am very worried about some of the ideas which are currently being aired. $\mathrm{He}$ is right; a static model of security based on notions of custody will do immeasurable harm to our psychiatric services in a number of ways. Not only will it bring a negativistic philosophy back into psychiatry but it could well convince a lot of hard-pressed general psychiatrists and nurses that mentally abnormal offenders and difficult patients are no longer their responsibility. "Oh, he's forensic, he should go to the security unit" could become the cry of the future. Indeed, such attitudes already exist and partly account for the increasing pressure on special hospitals.

Perhaps Dr Price will be encouraged to learn that at least one region is adopting a dynamic model rather along the lines he suggests, although we are concerned with NHS facilities and will not have formal links with prisons. In the South-east Thames Regional Health Authority we are not proposing to have a security unit; instead there 